\title{
Use of Formal and Informal Food Resources by Food Insecure Families in Lima, Peru: A Mixed-Methods Analysis
}

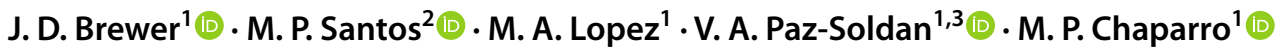

Accepted: 10 April 2021 / Published online: 27 April 2021

(c) The Author(s) 2021

\begin{abstract}
The goal of this study was to measure food insecurity among families with children in a low-income district of Lima, Peru and to identify the formal and informal food resources available to them that may affect their food security status. In JuneJuly 2019, we collected data from 329 randomly selected households in Villa El Salvador (Lima, Peru). Following a mixed methods approach, we found that the percentage of households using food assistance programs (FAPs) increased with increasing levels of food insecurity, but two FAPs were heavily used by households regardless of food (in)security. The main reasons for using FAPs included financial need, already being signed up in the program, and believing that the food was of nutritional value; the main reasons for non-use were finding the program unnecessary, dislike or poor perceived quality of the food, and not being able to sign up for the program. Similarly, informal food resources, such as buying food on credit or receiving food from someone outside the household, were incrementally used with increased levels of food insecurity. Our study clarifies the relationship between level of household food insecurity and FAP use - FAPs more commonly used by food insecure households were used because of financial need, whereas the FAPs most commonly used by food secure households were those with automatic enrollment. At a programmatic level, our research highlights the need for making nutritious and preferred foods available in FAPs and standardizing the application of enrollment criteria.
\end{abstract}

Keywords Food insecurity $\cdot$ Food assistance programs $\cdot$ Food resources $\cdot$ Coping strategies $\cdot$ Peru

\section{Introduction}

Food security "exists when all people, at all times, have physical and economic access to sufficient, safe, and nutritious food to meet their dietary needs and food preferences" [1]. Food insecurity, thus, refers to the inability to acquire adequate nutritious foods due to economic constraints and can be measured on a continuum as mild, moderate, or severe. In 2019, 2000 million (over 25\%) of people

J. D. Brewer

jbrewer7@tulane.edu

1 School of Public Health and Tropical Medicine, Department of Global Community Health and Behavioral Sciences, Tulane University, 1440 Canal Street, New Orleans, Louisiana 70112, USA

2 School of Public Health and Tropical Medicine, Department of Biostatistics and Data Science, Tulane University, 1440 Canal Street, New Orleans, Louisiana 70112, USA

3 Asociación Benéfica PRISMA, Avenida Santo Toribio 115, 5th floor, San Isidro, 15073 Lima, Peru worldwide experienced moderate or severe food insecurity [2]. In Latin America, 191 million people experienced moderate or severe food insecurity in 2019, representing $31.7 \%$ of the region's population, up from $22.6 \%$ in 2014 [2]. Food insecurity has been linked to a number of negative nutritional outcomes, such as wasting and underweight, stunting, and overweight/obesity, depending on the specific context and the age group under study [3]. The type of food assistance that families have access to, both formal (i.e. food assistance programs; FAPs) and informal (i.e. buying food on credit, exchanging goods and services for food), can contribute to their risk of food insecurity and/or be used to mitigate the effects of food insecurity.

Both FAP use and use of informal food resources have a bi-directional relationship with food insecurity - these resources are more likely to be used by those who are food insecure, but their use can also lead to decreased food insecurity. For example, in countries such as Uruguay, Mexico, and the United States, studies have found use of FAPs is more common among food insecure households and individuals [4-8]. However, research in Mexico and the United 
States has shown that participation in FAPs can lead to decreased household food insecurity $[9,10]$. In terms of informal food resources, previous research has shown that greater social capital and being a member of an organization were associated with decreased risk for food insecurity, since families with these characteristics frequently participated in meal sharing [11-13]. In contrast, studies in rural parts of Ethiopia, Nigeria, and the United States found that food insecure households are more likely to borrow money than food secure households [13-15].

In Peru, food insecurity is not routinely measured in national health surveys. However, a recent summary from the Young Lives study, an ongoing cohort study of families with children in 20 urban and rural districts in Peru, reported that food security increased from $27 \%$ in 2009 to $44 \%$ in 2013, with an associated decrease in mild and moderate food insecurity [16]. However, severe food insecurity increased from $7.5 \%$ to $11 \%$ in the same time period, and this increase was driven by urban poor families [16]. The Peruvian government funds several FAPs to address food insecurity and other nutritional concerns. These operate primarily in lowincome neighborhoods and are partly managed by community members.

Noteworthy FAPs include: Comedor Popular, a community kitchen program which provides low-cost meals to people living in poverty; Vaso de Leche, or "Glass of Milk", which distributes rations of $250 \mathrm{~mL}$ of fortified dairy- or grain-based milk to families with young children and other vulnerable individuals; Cuna Más, an early childhood development program that provides childcare and two meals per day to young children; and Qali Warma, the school feeding program, which provides a breakfast of a drink (dairy-, fruit-, or grain-based) and a baked product or a lunch of a non-perishable food item (grain, tuber, or protein-based preserve) to children in public primary schools [17-20]. Even though Comedor Popular and Vaso de Leche target families living in poverty in low-income neighborhoods, there is no hard criteria to enroll beneficiaries. Participants are selected at the discretion of local mother's committees who administer the programs, without the need for earnings' documentation. Additionally, at Comedor Popular, if there are leftover meals after enrolled participants have eaten, non-participants can purchase a reduced-cost meal. On the other hand, Qali Warma automatically enrolls all children in schools where the program is available, whether or not the individual child has a need for the program, though the program is only available in public schools in low-income neighborhoods. For a detailed breakdown of program eligibility criteria, see Table 1 . At the community level, research has recorded a number of informal coping strategies for food access in Peru, such as buying food on credit [21] or borrowing money for food [22], bartering services for food [21],

Table 1 Compared eligibility for Food Assistance Program (FAP) use according to program's target population, questions included in the questionnaire, and study data analysis plan

\begin{tabular}{|c|c|c|c|}
\hline Food assistance program & Program target population & $\begin{array}{l}\text { Question on FAP participation asked } \\
\text { if: }\end{array}$ & Coded as eligible to participate if: \\
\hline Comedor popular & $\begin{array}{l}\text { People living in poverty/extreme } \\
\text { poverty. Beneficiaries chosen at dis- } \\
\text { cretion of mothers' committees in } \\
\text { neighborhood; non-participants can } \\
\text { receive leftover meals at reduced } \\
\text { cost, if available }\end{array}$ & $\begin{array}{l}\text { Previously answered that there was a } \\
\text { Comedor Popular in their neighbor- } \\
\text { hood }\end{array}$ & $\begin{array}{l}\text { Answered positively that there was } \\
\text { a Comedor Popular in their neigh- } \\
\text { borhood }\end{array}$ \\
\hline Vaso de Leche & $\begin{array}{l}\text { 1st priority: children under the age of } \\
6 \text {, pregnant and lactating women. } \\
\text { 2nd priority: children aged } 7-13 \text {, } \\
\text { elderly, tuberculosis patients; poor/ } \\
\text { extreme poor. Beneficiaries chosen } \\
\text { at discretion of mothers' committees } \\
\text { in neighborhood }\end{array}$ & $\begin{array}{l}\text { For all children in household under } \\
\text { the age of } 18\end{array}$ & $\begin{array}{l}\text { Households with at least one child } \\
\text { under the age of } 14^{\mathrm{a}}\end{array}$ \\
\hline Cuna Más & $\begin{array}{l}\text { Children under the age of } 3 \text { who live } \\
\text { in poverty }\end{array}$ & $\begin{array}{l}\text { For all children in household under } \\
\text { the age of } 3\end{array}$ & $\begin{array}{l}\text { Households with at least one child } \\
\text { under the age of } 3\end{array}$ \\
\hline Qali Warma & $\begin{array}{l}\text { Children enrolled in public kindergar- } \\
\text { tens and primary schools }\end{array}$ & $\begin{array}{l}\text { For all children aged } 6-18 \text { years old } \\
\text { for whom the respondent previously } \\
\text { answered positively regarding the } \\
\text { child's school participating in Qali } \\
\text { Warma }\end{array}$ & $\begin{array}{l}\text { Households with at least one child } \\
\text { aged 6-13 }\end{array}$ \\
\hline
\end{tabular}

${ }^{\text {a }}$ While we inquired participation for all children $(<18$ years old), only the 1 st and 2 nd priority groups of minors $(<14$ years of age) was considered eligible, as only two children over 13 years received Vaso de Leche

${ }^{\mathrm{b}}$ Only school-aged children were considered eligible, as Qali Warma is served only in primary school (6-13 years old) and only 3 non-school aged children reported participating in Qali Warma 
and hosting polladas (community-organized fried chicken sales for the purpose of fundraising) [23].

Research connecting food security with the use of these formal and informal food resources in Peru is lacking. To our knowledge, no studies have evaluated how FAP use is associated with food insecurity in Peru. Similarly, studies on the connection between informal food resource use and food insecurity are limited - two studies in Peru have found that social connectedness or capital were associated with food security [24, 25] and only one in the Amazon Region specified how certain coping strategies, such as gifting and receiving food, improved food security [21]. Given that severe food insecurity in Peru is increasing particularly among the urban poor [16] and that people living in urban poverty have unique experiences and challenges related to food insecurity [26], the goal of this study was to identify the formal and informal food resources available to, and used by, food insecure families living in an urban poor district of Lima, Peru. This research is increasingly pertinent as economic access to food and FAP accessibility have been limited by the COVID-19 pandemic in Peru [27].

\section{Methods}

\section{Study Setting}

Our study took place in Villa El Salvador (VES), a lowincome district in Lima, the capital of Peru. VES is the fifth largest district in Metropolitan Lima, with approximately 463,014 residents in 2015 [28], 20-25\% of whom lived in poverty in 2017 [28]. VES is located in the southern cone of Metropolitan Lima, which accounts for a large proportion of households of low socioeconomic status compared to the city center, a distinction linked to a historical concentration of migration in the city's peripheral districts [29]. VES started as an informal settlement of squatter communities who did not have formal ownership of their land; however, residents organized to obtain legal land titles and public services over time $[29,30]$. This social movement also manifested in women's and mothers' committees, which worked to create precursors to government-funded FAPs, such as Vaso de Leche and Comedor Popular [31].

\section{Study Design}

In order to identify the food resources available for, and utilized by, food insecure families, we collected data via a household questionnaire. We estimated that a sample of 450 participant households was necessary to detect a prevalence of food insecurity of 56\% [16] with a power of $80 \%$ and margin of error of 5\%, assuming an $80 \%$ complete response rate. Given that poverty is the main risk factor for food insecurity, we wanted to evaluate how food insecurity and food resource availability and utilization differed across households of different income strata. Therefore, we randomly sampled 150 neighborhood blocks from each of the three income strata present in VES: low income (average monthly income less than US \$164), lower-middle income (average monthly income US \$164-256), and middle income (average monthly income US \$256-379) [32]. We recruited one household per neighborhood block via systematic sampling until we found a household that fit the eligibility criteria and consented to participate in the survey. Eligibility criteria included that the respondent had to be in charge of food purchase in the home, be at least 18 years of age, and have at least one child ( $<18$ years old) living in the household.

\section{Data Collection}

All data were collected between June-July 2019. The research team included three experienced local data collectors plus three US-based research assistants with training in public health research. We attempted recruitment with 2267 households; over half of these households did not answer the door or were ineligible to participate. Of the eligible 714 with which we made contact, 329 households participated in and completed the questionnaire, for a cooperation rate of $46.1 \% ; 104$ of the households that completed the survey were from lower-income neighborhood blocks, 121 from lower-middle income blocks, and 104 from middle income blocks.

\section{Study Instrument}

The household questionnaire included demographic and socioeconomic questions, the Household Food Insecurity Access Scale (HFIAS), and questions on FAP participation and informal methods of food access. The questionnaire was first piloted for validation with 19 conveniently-sampled households in the district of San Juan de Lurigancho, which has similar socioeconomic characteristics as VES.

To measure the presence and severity of food insecurity, we utilized HFIAS, an internationally validated 18-question scale [33] which has been translated into Spanish and validated in previous studies in Peru [34]. The section on FAP participation and informal methods of food access was designed by our study team based on similar studies measuring food resources in Peru [21, 25, 35]. Respondents were asked if they participated in any of the following FAPs: Comedor Popular, Vaso de Leche, Cuna Más, and Qali Warma. The respondent was asked if they had used the programs only if they met the eligibility criteria outlined in Table 1. Respondents were then asked open-ended questions about the main reasons why they reported using the program (if reported use was within 6 months prior to the survey) or 
not using the program. Even though questions about FAP use and reasons for use/non-use were asked for each eligible child in the household, we report use and reasons for use/ non-use at the household level.

For informal food resources, participants were asked if in the 7 days prior they did any of the following: purchased food on credit, borrowed money to purchase food, received food for free from someone who is not a member of their household (excluding food obtained through FAPs), or prepared food with someone who is a not a member of their household. Respondents were asked about these informal food resources over the previous 7 days because of the assumption that these methods may be more difficult for respondents to recall over a longer period of time.

\section{Quantitative Data Analysis}

We ran descriptive statistics (i.e. frequencies) to summarize the use of formal and informal food resources among eligible respondents according to severity (mild, moderate, severe) of household food insecurity (Table 2). Use of formal food resources (i.e. FAPs) was estimated both for the previous 4 weeks to match the timeframe of the food insecurity questions, and for the previous 6 months to match the timeframe of the qualitative responses. Use of informal food resources was estimated for the previous 7 days as that was the only timeframe measured. Additionally, we ran chi-square tests to identify significant differences in the use of FAPs and informal food resources by severity of food insecurity, with a p-value of $<0.05$ considered statistically significant.

\section{Qualitative Data Analysis}

Each step of the qualitative data analysis process was conducted separately for each open-ended question, creating a unique codebook for use and non-use of each FAP. The primary coder [JDB] developed the first version of the codebooks through line-by-line coding of all data points, following a grounded theory approach [36]. Codes were validated with expert-checking, presenting the codebooks and example quotes to the study's local data collectors, who used their familiarity of the study location and FAPs to confirm the code relevance and suggest changes. The primary coder then used this feedback to edit the codebooks and re-code all data. The primary coder combined or divided codes for additional clarity, producing the final versions of the codebooks. At this point, the primary and secondary coder [JDB, MAL] coded all data with the finalized codebooks using qualitative analysis software NVivo 12, blind double-coding every fifth data point. The coders attained kappa scores ranging

Table 2 Use of formal and informal food resources among eligible respondents by severity of household food (in)security, Villa El Salvador (Lima, Peru)

\begin{tabular}{|c|c|c|c|c|c|}
\hline & \multirow{2}{*}{$\begin{array}{l}\text { Total eligi- } \\
\text { ble, } \mathrm{N}\end{array}$} & \multirow[t]{2}{*}{ Food secure (\%) } & \multicolumn{3}{|c|}{ Food insecure } \\
\hline & & & Mild (\%) & Moderate $(\%)$ & Severe $(\%)$ \\
\hline Interviewed households & 329 & 22.8 & 14.9 & 24.0 & 38.3 \\
\hline \multicolumn{6}{|l|}{ Formal food resource use in past 6 months ${ }^{\mathrm{a}}$} \\
\hline Comedor Popular & 137 & 40.0 & 58.3 & 58.3 & 62.5 \\
\hline Vaso de Leche* & 298 & 21.2 & 23.4 & 36.0 & 42.7 \\
\hline Cuna Más & 141 & 0 & 5.0 & 5.0 & 6.1 \\
\hline Qali Warma & 237 & 42.0 & 40.5 & 36.0 & 52.0 \\
\hline \multicolumn{6}{|l|}{ Formal food resource use in past 4 weeks $^{\mathrm{a}}$} \\
\hline Comedor Popular & 137 & 28.0 & 33.3 & 41.7 & 37.5 \\
\hline Vaso de Leche* & 298 & 19.7 & 21.3 & 34.7 & 37.3 \\
\hline Cuna Más & 141 & 0 & 5.0 & 5.0 & 6.1 \\
\hline Qali Warma & 237 & 42.0 & 40.5 & 36.0 & 50.0 \\
\hline \multicolumn{6}{|l|}{ Informal food resource use in past 7 days } \\
\hline Purchased food on credit*** & 329 & 9.3 & 14.3 & 38.0 & 53.2 \\
\hline Borrowed money to purchase food $* * *$ & 329 & 2.7 & 4.1 & 16.5 & 31.0 \\
\hline Received food from someone outside of household $* *$ & 329 & 14.7 & 18.4 & 38.0 & 29.4 \\
\hline Prepared food with someone outside of household & 329 & 20.0 & 16.3 & 21.5 & 24.6 \\
\hline
\end{tabular}

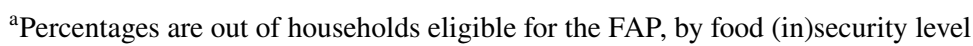

Statistical significance based on Likelihood Chi-Square is denoted by:

$* \mathrm{p}<0.05$

$* * \mathrm{p}<0.01$

$* * * \mathrm{p}<0.001$ 
from 0.74 to 1.00 for each question codebook, demonstrating high inter-rater reliability. Qualitative results for Cuna Más are not included as only 6 respondents participated in this program.

\section{Results}

\section{Quantitative Results}

In general, the use of formal food resources increased as severity of food insecurity increased, though the only significant difference was observed for Vaso de Leche (Table 2). The most commonly used FAP for food insecure households in the 6 months prior to the survey was Comedor Popular. When measured in the previous 4 weeks, this shifted to Qali Warma for all levels of food insecurity except moderately food insecure. The most commonly used FAP for food secure households was Qali Warma, at both 6 months and 4 weeks. Interestingly, use of FAPs was highly prevalent among food secure households, who heavily relied on both Qali Warma and Comedor Popular. The least used FAP across all levels of severity of food (in)security was Cuna Más.

Use of informal food resources also increased with increased severity of food insecurity; this observed increase was statistically significant for all categories except for "prepared food with someone outside the household" (Table 2). The most commonly used informal food resource varied at each level of food (in)security: food secure households tended to prepare food with someone outside the household, mildly food insecure households reported receiving food from someone outside the household, moderately food insecure households reported both receiving food from someone outside the household and purchasing food on credit, and severely food insecure households tended to purchase food on credit.

\section{Qualitative Results}

The most common reasons for using or not using FAPs varied by FAP. Below, we report the most frequently occurring themes for use and non-use for each FAP.

\section{Comedor Popular}

Of the reasons that respondents gave for utilizing Comedor Popular, the most frequently occurring themes were financial need and time. For example, when asked the main reason they attended the Comedor Popular, one respondent shared that they went, "when money gets tight for cooking" and another said because, "I save on gas and oil." Other responses related to being unable to cook their own food, "due to a lack of time to cook", feeling rushed, not being in the house to cook, or simply not wanting to cook.

Alternatively, the most frequently occurring themes for why respondents did not use Comedor Popular included feeling that it was unnecessary, i.e., they perceived they had no need to participate in the program, and due to the quality of the food itself. In regards to finding the program unnecessary, some respondents simply explained, "There is no need," while others elaborated, "I work and have enough to cook," and, "It is for people who need it more." With respect to the quality of the food, a few respondents stated, "It is not the same what I cook" and "We do not like the food." Others claimed, "The food is not nutritious."

\section{Vaso de Leche}

The most frequently occurring themes for using Vaso de Leche were that respondents were already signed up, financial reasons, and because they believe the food provided nutritional value. A vast majority of respondents stated the main reason they participated in the program was because they were already signed up and received the food, or because they felt it was their right to receive the food. Many respondents explained they received Vaso de Leche, "for [the child's] breakfast" or "because of [the child's] age and because she is signed up." Others specified that they received Vaso de Leche, "because the government gives it to [the child]." Financial reasons ranged from feeling a need for the ration (e.g. "It is necessary for me, and sometimes there is no money,") to finding it advantageous compared to buying food (e.g. "It is in our best interest instead of buying milk"). In terms of the nutritional quality of the food, many respondents emphasized the presence of oatmeal in the food ration, with a few specifying, "It is good to eat oatmeal." Others spoke generally of the nutritional value of the food, "It reinforces [the child's] diet."

Alternatively, the most frequent themes for not using Vaso de Leche were related to not being registered for the program. First, respondents stated that they were not allowed to sign up or were deemed ineligible for various reasons: "They did not let me sign up," or "Due to [the child's] age, they no longer give it to him," or "They did not want to give it to me because I have a fully constructed house [measure of socioeconomic status]." The second most common reason for not using Vaso de Leche was simply not being signed up at the present moment, but without evidence that they were not allowed to sign up or had tried to and were unable. Many respondents simply responded, "We are not signed up," while some added, "They do not come to sign us up." Following reasons related to registration, respondents also gave reasons related to the food (e.g. "They always prepare the same thing," and, "I do not think it is healthy food") and 
feeling that the program was unnecessary for them (e.g. "Here at home we have food").

\section{Qali Warma}

The overwhelming amount of responses for why respondents' children consumed foods from Qali Warma were because the children were given the food because the child is in a school with the program: "They give it to [the child] in school," and, "They give it to all children," while some specified, "They are in school and the government has an obligation to give it to them." The following most frequent themes for consuming Qali Warma had to do with an aspect of the food, either liking the food (e.g. "[The child] like the cookies and the milk too") or expressing that it has nutritional value (e.g. "They give it to [the child] for its vitamins," and, "For nourishment").

Of the 107 respondents who said their children attended a school with Qali Warma, only nine said their child did not eat the food. Seven out of the nine responses for the main reason the child did not eat the food were related to an aspect of the food, either a dislike for the food ("[The child] does not like it") or doubting the quality of the food, ("He does not eat it because he gets food that is in poor condition").

\section{Conclusions}

Our study aimed to identify the formal and informal food resources available to, and used by, food insecure families living in an urban poor district of Lima, Peru. Our findings add to a body of evidence from other countries that food insecure households have high participation rates in FAPs compared to food secure households [4, 6-8]. However, we also found heavy use of FAPs among the food secure. This could be because all households under study were from a low-income neighborhood, thus even those households that were food secure were not wealthy and had easy accessibility to FAPs.

Similarly, our results showed increasing proportions of households using informal food resources at each increasing level of food insecurity. This differs from previous findings in Peru that showed informal food resource use or similar intangibles were associated with decreased food insecurity $[21,24,25]$. This may be because two of these studies focused on social networks, rather than specific coping mechanisms, [24, 25] and the third, which assessed gifting and receiving food, was conducted in the Amazon Region where practices around food sharing may be different [21]. Our findings are consistent with studies in other parts of the world that show that use of informal food resources, such as borrowing money, increases with increasing food insecurity [13-15]. Given the flexible nature of some FAPs in Peru, the use of informal food resources may be more telling of a household's food insecurity, specifically purchasing food on credit and borrowing money to buy food, which steadily increased with increasing levels of food insecurity in our study.

Our qualitative findings of reasons for FAP use and nonuse were consistent with the literature. Other qualitative and mixed-methods studies in Argentina, the US, Canada, and the UK support our findings that financial need is a principal reason for FAP use [13, 37-39]. Research in Argentina, Brazil, and the US supports our findings of ineligibility, lack of access, and other system hassles as primary barriers to FAP participation [13, 37, 40]. Additionally, research in Canada and of Latinos living in the US found that not having access to preferred foods limited participants' abilities to use food banks as many participants desired foods of better nutritional quality [38, 41]. This is comparable to our findings that concerns about food preference and nutritional quality were primary reasons for not using FAPs.

By using mixed methods, our study explored relationships between food (in)security and food resource use that may not be captured in research relying on only quantitative or qualitative data. For example, financial need was a main reason for using both the Comedor Popular and Vaso de Leche, and we saw that use of these programs tended to increase with increasing severity of food insecurity. This may suggest that these two programs are reaching their target population of those with financial need. Alternatively, most people reported their children consumed food from Qali Warma because it was given to them in school, not necessarily because of financial need. This could explain why food secure households most frequently used Qali Warma. The different qualitative and quantitative results for these programs can be explained by their structures-Comedor Popular and Vaso de Leche require individuals to sign up, whereas Qali Warma is given out to all children in public schools where it is present, regardless of individuals' needs.

This study shows some possible areas of intervention to make FAPs more effective in addressing food insecurity in urban areas of Peru. Issues related to food were prominent reasons for non-use across FAPs. It is important that FAPs provide food that is both nutritious and fitting of beneficiaries' tastes and preferences. Research has found that some foods provided by FAPs in Peru are nutritionally insufficient $[20,42-45]$ and simultaneously high in carbohydrates, sugars, and saturated fat, [42, 43] but research on beneficiaries' perceptions of these foods is more limited [45, 46]. Additionally, there were particular concerns with Vaso de Leche about respondents being considered ineligible or not allowed to sign up for other reasons. Though many respondents did not participate because they did not meet standard program eligibility criteria, there seemed to be inconsistent application of this criteria (for example, respondents cited different age cut-offs) or application of subjective criteria (e.g. owning a 
business or having a fully constructed house as evidence of socioeconomic status that precludes participation). Furthermore, many respondents were not given any reason for why they could not participate. This confusion around eligibility is likely due to the fact that, though the government sets forth criteria for first and second priority target populations, the final decision on enrollment is at the discretion of local mothers' committees, so application of criteria is subjective. Previous studies have shown that actual users of various FAPs in Peru do not always meet government eligibility criteria [20, $44,45,47-49]$. The flexibility around eligibility criteria in Peru is an important distinction from the more standardized practices in countries where the overwhelming majority of research on FAPs takes place, and thus needs to be considered in both scientific studies and policy proposals.

This research has a number of strengths. To our knowledge, it is the first study in Peru to assess FAP use by level of food (in)security, and one of the first to investigate this and the use of informal food resources among the urban poor in Peru. It used a stratified random sample; thus the data can be considered representative of the low-income district under study and possibly other similar districts within Lima. Finally, qualitative themes about FAP use/non-use were validated via expert-checking with local data collectors.

However, the study also needs to be seen in light of certain limitations. First, different timeframes were used to measure FAP and informal food resource use (past 6 months or past 4 weeks, and past 7 days respectively), which may complicate comparisons between the use of these resources. Different timeframes were assigned to FAP and informal resource use to replicate similar questions in previous studies in Peru [21, 35] and because of the assumption that it may be harder to recall informal food resource use beyond 7 days, whereas FAP use is usually continuous. A second limitation was that all qualitative data came from a small series of short-answer questions, nested within a 30-min household questionnaire where answers were typed by data collectors into a tablet. Compared to voice recordings, this form of data collection may have resulted in the loss of some level of detail or been susceptible to observer bias. Additionally, qualitative data from a survey format is naturally more limited than other qualitative methods, like in-depth interviews, which could more naturally capture narratives of how participants began using FAPs. Third, slightly different wording between open-ended questions for each FAP may have led to responses that are hard to compare across FAPs. For example, we asked, "What is the main reason you go to the Comedor Popular?" compared to, "What is the main reason the child eats Vaso de Leche?" The latter question focuses on consuming the Vaso de Leche ration and not the reason for household participation in order to allow for separate responses for each child in the household, not only eligible children. This was to capture household sharing of Vaso de Leche food rations with non-eligible family members, which we found in our study and has been cited in the literature [46-48]. Finally, the differences between FAP eligibility criteria for our questionnaire and data analysis, as well as from program standards (Table 1), may have created some discrepancies in analysis. The purpose for these distinctions was to capture as large a breadth of FAP users from the questionnaire, but then minimize the number of eligible respondents for analysis so as to not inflate non-use. Given the flexible and inconsistent application of program criteria, [47, 48] we felt that only surveying respondents who fit program criteria would result in excluding a considerable number of families who used the FAP despite not being eligible.

Future studies would benefit from creating a purposive sample of households that are eligible for or participate in Cuna Más, as the number of Cuna Más participants was negligible in our study. It would be valuable to capture the state of food (in)security among Cuna Más beneficiaries as well as collect qualitative data on why eligible families do or do not participate in the program. This would allow researchers and policymakers to understand if Cuna Más is reaching its target population and possible barriers or enablers to program use. Additionally, given the predominance of "food quality" as a theme for both FAP participation and non-participation, this study could be complemented by further research on beneficiaries' perceptions of the quality of, and their preferences for, the food offered at FAPs in Peru. The food security construct includes not only quantity of food available, but also access to nutritious foods that meet food preferences [1]. Therefore, if FAPs aim to address issues of food insecurity, it is important that researchers and policymakers alike pay attention to what kind of food is available in these programs and what beneficiaries think of them.

Further, the ongoing COVID-19 pandemic and associated economic crisis has highlighted the urgency to identify alternative ways for governments to provide food to those in need. For large parts of 2020, FAPs in Peru were not able to operate in normal capacity due to shutdowns and social distancing measures. Reconsidering the distribution patterns of traditional food assistance is thus warranted. Moreover, in times of crises such as the current one, informal food resources may become significantly more important than FAPs at helping people deal with food access issues. Future studies should further investigate these types of communal assistance as important coping mechanisms for food insecure families living in urban poverty in times of crisis.

Acknowledgements We would like to thank Lilia Cabrera, Blanca Delgado, Nelly Briceño, and Rafael Duran, as well as other staff of the Asociación Benéfica PRISMA field site in Villa El Salvador, for their work in project logistics and administration, participant recruitment, implementation of household surveys, and validation of study results. Additionally, we would like to thank Dr. Richard Oberhelman, of Tulane University School of Public Health \& Tropical Medicine, for his leadership in funding acquisition.

Authors' Contributions Conceptualization: JDB, VAP-S, MPC; Data curation: MPS, MAL; Formal analysis: JDB, MPS, MAL; Funding 
acquisition: VAP-S, MPC; Investigation: JDB, MPS, MAL Methodology: JDB, MPC; Project Administration: JDB, MPC; Resources: VAPS; Software: MPS, MAL, MPC; Supervision: VAP-S, MPC; Validation: MPS, MAL, MPC; Visualization: JDB, MPS; Writing- original draft: JDB; Writing- review \& editing: JDB, MPS, MAL, VAP-S, MPC.

Funding This study was funded by: National Institute on Minority Health and Health Disparities, "Tulane-Xavier Minority Training in International Health" through the Minority Health International Research Training (MHIRT) Program (T37 MD001424). Fulbright U.S. Student Program Carol Lavin Bernick Faculty Grant, Tulane University Office of the Provost. Please note, the conclusions expressed in this paper are entirely those of the listed authors and are not endorsed by the Fulbright Program, the U.S. Department of State, or any of its partner organizations. None of the funders had any role in study design, data collection and analysis, decision to publish, nor preparation of the manuscript.

Data Availability The original data collected in this study can be made available at the request of the journal and/or reader.

Code Availability The most frequently occurring qualitative codes, example quotes, and range of kappa scores for the codebooks can be found in the manuscript. Additional information, such as code definitions, code frequency, and specific kappa scores, can be made available at the request of the journal and/or reader.

\section{Declarations}

Conflict of interest The authors have no relevant financial or non-financial interests to disclose.

Ethical Approval This research project was reviewed and approved by the Institutional Review Boards (IRBs) of Tulane University School of Public Health and Tropical Medicine in New Orleans, Louisiana, USA (\#2019-614) and the nonprofit organization Asociación Benéfica PRISMA in Lima, Peru (CE0513.19).

Consent to Participate All study participants gave their written consent in electronic format (or paper format, as needed) before participating in the questionnaire, as approved by all IRBs, and were given a written copy of the consent script to keep.

Open Access This article is licensed under a Creative Commons Attribution 4.0 International License, which permits use, sharing, adaptation, distribution and reproduction in any medium or format, as long as you give appropriate credit to the original author(s) and the source, provide a link to the Creative Commons licence, and indicate if changes were made. The images or other third party material in this article are included in the article's Creative Commons licence, unless indicated otherwise in a credit line to the material. If material is not included in the article's Creative Commons licence and your intended use is not permitted by statutory regulation or exceeds the permitted use, you will need to obtain permission directly from the copyright holder. To view a copy of this licence, visit http://creativecommons.org/licenses/by/4.0/.

\section{References}

1. Rome Declaration and Plan of Action. Accessed February 7, 2019. http://www.fao.org/docrep/003/w3613e/w3613e00.htm
2. FAO F (2020) Panorama de la seguridad alimentaria y nutricional en América Latina y el Caribe 2020 Seguridad alimentaria y nutricional para los territorios más rezagados. FAO, OPS, WFP and UNICEF; 2020. doi: https://doi.org/10.4060/cb2242es

3. Ghattas H. Food Security and Nutrition in the context of the Global Nutrition Transition. Food and Agriculture Organization of the United Nations. Published online 2014:21.

4. Rossi, M., Ferre, Z., Curutchet, M. R., Giménez, A., \& Ares, G. (2017). Influence of sociodemographic characteristics on different dimensions of household food insecurity in Montevideo. Uruguay. Public Health Nutrition., 20(4), 620-629. https://doi. org/10.1017/S1368980016002548

5. Shamah-Levy, T., Mundo-Rosas, V., Morales-Ruan, C., CuevasNasu, L., Méndez-Gómez-Humarán, I., \& Pérez-Escamilla, R. (2017). Food insecurity and maternal-child nutritional status in Mexico: cross-sectional analysis of the National Health and Nutrition Survey 2012. British Medical Journal Open, 7(7), e014371. https://doi.org/10.1136/bmjopen-2016-014371

6. Mayer, V. L., Hillier, A., Bachhuber, M. A., \& Long, J. A. (2014). Food insecurity, neighborhood food access, and food assistance in Philadelphia. Journal of Urban Health, 91(6), 1087-1097. https://doi.org/10.1007/s11524-014-9887-2

7. Hilmers, A., Chen, T.-A., \& Cullen, K. W. (2014). Household Food Insecurity and Dietary Intake among Mexican-American Women Participating in Federal Food Assistance Programs. American Journal of Health Promotion, 28(6), e146-e154. https://doi.org/10.4278/ajhp.130104-QUAN-13

8. Choi, S. K., Fram, M. S., \& Frongillo, E. A. (2017). Very low food security in us households is predicted by complex patterns of health, economics, and service participation. Journal of Nutrition, 147(10), 1992-2000. https://doi.org/10.3945/jn. 117.253179

9. Huang, J., Kim, Y., \& Barnidge, E. (2016). Seasonal difference in national school lunch program participation and its impacts on household food security. Health and Social Work, 41(4), 235-243. https://doi.org/10.1093/hsw/hlw043

10. Mundo-Rosas, V., Vizuet-Vega, N. I., Martínez-Domínguez, J., Morales-Ruán, M. D. C., Pérez-Escamilla, R., \& Shamah-Levy, T. (2018). Evolution of food insecurity in Mexican households: 2012-2016. Salud Publica de Mexico, 60(3), 309-318. https:// doi.org/10.21149/8809

11. Martin, K. S., Rogers, B. L., Cook, J. T., \& Joseph, H. M. (2004). Social capital is associated with decreased risk of hunger. Social Science and Medicine, 58(12), 2645-2654. https:// doi.org/10.1016/j.socscimed.2003.09.026

12. King, C. (2017). Informal assistance to urban families and the risk of household food insecurity. Social Science and Medicine, 189, 105-113. https://doi.org/10.1016/j.socscimed.2017.07.030

13. Swanson, J. A., Olson, C. M., Miller, E. O., \& Lawrence, F. C. (2008). Rural mothers' use of formal programs and informal social supports to meet family food needs: a mixed methods study. J Fam Econ Iss., 29(4), 674-690. https://doi.org/10.1007/ s10834-008-9127-6

14. Mukhtar, M. (2019). Food insecurity and coping strategies among rural households in niger state. Nigeria. lje., 3(1), 92-107

15. Muche, M., Endalew, B., \& Koricho, T. (2014). Determinants of household food security among southwest ethiopia rural households. Food Science and Technology., 2(7), 93-100. https://doi. org/10.13189/fst.2014.020701

16. Penny M, Melendex G. Growth and Nutrition: Round 4 preliminary findings. Published online January 2015. https://www.young lives.org.uk/sites/www.younglives.org.uk/files/PER-Growth\% 26Nutrition-Factsheet.pdf 
17. Ministerio de Desarrollo e Inclusión Social. Componente Alimentario. Qali Warma. Accessed September 16, 2020. https://www. qaliwarma.gob.pe/que-ofrecemos/componente-alimentario/

18. Ministerio de Desarrollo e Inclusión Social. Programa NacionalCuna Más. www.cunamas.gob.pe

19. Ministerio de Salud. Guía: Formulación de la Ración del Programa del Vaso de Leche. Published online 2010. https://www.ins. gob.pe/insvirtual/images/otrpubs/pdf/IMPRESION\%20\%20vaso\% 20ok.pdf

20. Alcazar L. [Why food assistance and nutritional programs in Peru do not work? Risks and opportunities for their reform.]. In: [Research, Policies, and Development in Peru]. GRADE; 2007.

21. Ambikapathi, R., Rothstein, J. D., Yori, P. P., et al. (2018). Food purchase patterns indicative of household food access insecurity, children's dietary diversity and intake, and nutritional status using a newly developed and validated tool in the Peruvian Amazon. Food Secur., 10(4), 999-1011. https://doi.org/10.1007/ s12571-018-0815-2

22. Limon, G., Fournié, G., Lewis, E. G., et al. (2017). Using mixed methods to assess food security and coping strategies: a case study among smallholders in the Andean region. Food Sec., 9(5), 1019-1040. https://doi.org/10.1007/s12571-017-0713-z

23. Alderete Á, Antenor M. La pollada: una forma de autoorganización para afrontar la crisis Lima, 1980-2001: una visión sociohistórica. Universidad Nacional Mayor de San Marcos. Published online 2018. Accessed December 13, 2019. https://cybertesis. unmsm.edu.pe/handle/20.500.12672/8793

24. Isquith-Dicker LN. Food security and social capital in an urban informal settlement in Lima, Peru. Published online April 6, 2016. Accessed February 8, 2019. https://digital.lib.washington.edu: 443/researchworks/handle/1773/35510

25. Lee, G. O., Surkan, P. J., Zelner, J., et al. (2018). Social connectedness is associated with food security among peri-urban Peruvian Amazonian communities. SSM Popul Health., 4, 254-262. https:// doi.org/10.1016/j.ssmph.2018.02.004

26. Tacoli C. Food (In)Security in Rapidly Urbanising, LowIncome Contexts. Int J Environ Res Public Health. 2017;14(12). doi:https://doi.org/10.3390/ijerph14121554

27. Zegarra E. La pandemia del COVID-19 y la inseguridad alimentaria en el Perú. GRADE. Accessed July 4, 2020. http://www. grade.org.pe/novedades/la-pandemia-del-covid-19-y-la-inseg uridad-alimentaria-en-el-peru-por-eduardo-zegarra/

28. Instituto Nacional de Estadística e Informática. Provincia de Lima: Compendio Estadístico 2017.; 2017.

29. Peters, P. A., \& Skop, E. H. (2007). Socio-spatial Segregation in Metropolitan Lima. Peru. Journal of Latin American Geography., 6(1), 149-171

30. Dosh PGJ. Demanding the Land: Urban Popular Movements in Peru and Ecuador, 1990-2005. Penn State Press; 2010.

31. Moyano, M. E., \& Miloslavich, T. D. (1993). Perú en busca de una esperanza. (1st ed.). Fundación Española para la Cooperación: Solidaridad Internacional.

32. Instituto Nacional de Estadística e Informática. Planos Estratificados de Lima Metropolitana a Nivel de Manzana 2016: Según Ingreso per Cápita Del Hogar, Según Grupos de Pobreza Monetaria.; 2016.

33. Coates, J., Swindale, A., \& Bilinsky, P. (2007). Household Food Insecurity Access Scale (HFIAS) for Measurement of Food Access: Indicator Guide: Version 3: (576842013-001). Published online. https://doi.org/10.1037/e576842013-001

34. Psaki, S., Bhutta, Z. A., Ahmed, T., et al. (2012). Household food access and child malnutrition: results from the eight-country MAL-ED study. Popul Health Metr., 10(1), 24. https://doi.org/ 10.1186/1478-7954-10-24
35. Cuestionarios - Niños del Milenio I Niños del Milenio. Accessed January 21, 2019. http://www.ninosdelmilenio.org/base-de-datosy-cuestionarios/cuestionarios/

36. Charmaz K. Constructing Grounded Theory: A Practical Guide through Qualitative Analysis. SAGE; 2006.

37. Lindsay, A. C., Ferarro, M., Franchello, A., et al. (2012). Child feeding practices and household food insecurity among lowincome mothers in Buenos Aires. Argentina. Ciênc Saúde Coletiva., 17, 661-669. https://doi.org/10.1590/S1413-8123201200 0300012

38. Holmes, E., Black, J. L., Heckelman, A., et al. (2018). "Nothing is going to change three months from now": A mixed methods characterization of food bank use in Greater Vancouver. Social Science and Medicine, 200, 129-136. https://doi.org/10.1016/j. socscimed.2018.01.029

39. Emergency Use Only: Understanding and reducing the use of food banks in the UK I Oxfam Policy \& Practice. Policy \& Practice. Accessed December 16, 2019. https://policy-practice.oxfam.org. uk/publications/*

40. Lindsay, A. C., Machado, M. T., Sussner, K. M., Hardwick, C. K., Kerr, L. R. F. S., \& Peterson, K. E. (2009). Brazilian mothers' beliefs, attitudes and practices related to child weight status and early feeding within the context of nutrition transition. Journal of Biosocial Science, 41(1), 21-37. https://doi.org/10.1017/S0021 932008003039

41. Wright, K. E., Lucero, J., \& Crosbie, E. (2020). "It's Nice to Have a Little Bit of Home, Even if It's Just on Your Plate" - Perceived Barriers for Latinos Accessing Food Pantries. Journal of Hunger \& Environmental Nutrition., 15(4), 496-513. https://doi.org/10. 1080/19320248.2019.1664963

42. Pillaca-Medina, S., \& Chavez-Dulanto, P. N. (2017). How effective and efficient are social programs on food and nutritional security? Food and Energy Security., 6(4), e00120. https://doi.org/10. $1002 /$ fes 3.120

43. Paredes-Aramburú, J., \& Bernabé-Ortiz, A. (2018). Asociación entre la participación en programas de asistencia alimentaria y patrones del perfil lipídico en Perú. Revista chilena de nutrición., 45(2), 135-143. https://doi.org/10.4067/s0717-751820180003001 35

44. Vasquez E. Propuesta de Reforma de Programas AlimentarioNutricionales En Peru. World Food Programme; 2010. https:// www.mimp.gob.pe/webs/mimp/sispod/pdf/177.pdf

45. Alcázar L. Algunas reflexiones sobre los programas alimentarios y nutricionales: cambios y retos durante la última década. :47.

46. CUANTO. Impact Evaluation of the Community Kitchen Program. Published online 2005. https://www.ins.gob.pe/insvirtual/ BiblioDig/MISC/COME/COMPOP05/IFComPop05.pdf

47. Lopez-Calix JR, Alcazar L, Seligson MA. Does Local Accountability Work? Tracing "Leakages" in the Peruvian Vaso de Leche Program. International Household Survey Network. Published 2010. Accessed September 16, 2020. https://catalog.ihsn.org/ index.php/catalog/1022/download/41025

48. Valdivia M. Peru : Is identifying the poor the main problem in targeting nutritional programs ? Accessed September 17, 2020. https://agris.fao.org/agris-search/search.do?recordID=US201 2410560

49. Las pérdidas en el camino, fugas en el gasto público: transferencias municipales, vaso de leche y sector educación I GRADE. Accessed September 17, 2020. https://www.grade.org.pe/en/publi caciones/506-las-perdidas-en-el-camino-fugas-en-el-gasto-publi co-transferencias-municipales-vaso-de-leche-y-sector-educacion/

Publisher's Note Springer Nature remains neutral with regard to jurisdictional claims in published maps and institutional affiliations. 